Ritrýnd grein birt 11. júní 2019

\title{
„GÆSin mín og GÆSin pín, Egils malt og appelsín“ Orðræðan um kaffihúsið GÆS
}

\author{
Ágústa Björnsdóttir og Jón Ingvar Kjaran
}

$\checkmark$ Abstract Um höfundana About the authors $>$ Heimildir

Fólk með proskahömlun hefur í gegnum tíðina verið jaðarsettur hópur og átt fá tækifæri til atvinnupátttöku á almennum vinnumarkaði. Árið 2013 stofnuðu fimm nemendur í starfstengdu diplómanámi fyrir fólk með proskahömlun við Háskóla Íslands kaffihúsið GÆS í starfsnámi sínu. Rannsóknin sem hér er til umfjöllunar hafði раð аð markmiði að draga fram og greina pá orðræðu sem skapaðist í samfélaginu um kaffihúsið GÆS en pað hlaut mikla umfjöllun á frétta- og vefmiðlum. Auk pess var leitast við að fá fram með hvaða hætti orðræðan um GÆS mótaði reynslu stofnfélaganna fimm og í pví skyni voru tekin einstaklings- og rýnihópaviðtöl við pau. Gögnin voru greind með orðræðugreiningu og pemagreiningu. Niðurstöður rannsóknarinnar benda til pess að orðræðan um GÆS hafi einkennst af jákvæðni í garð hópsins sem stóð að kaffihúsinu og birtist hún meðal annars í bví að fjölmiðlar og almenningur sýndi kaffihúsinu mikinn áhuga og velvild. Í mótsögn við ofangreinda orðræðu litaðist orðræðan einnig af staðalmyndum um fólk með proskahömlun sem byggjast meðal annars á pví að líta á fólkið sem eilíf börn. Pessar hugmyndir leiddu til pess að fram komu ýmsar efasemdir um getu hópsins til að reka kaffihús og átti pað stóran pátt í að rekstrinum var hætt. Jafnframt var stofnfélögunum fimm lýst sem ofurhetjum, snillingum og dugnaðarforkum á samfélagsmiðlum. Рó að orðræðan hafi á stundum virst viðhalda staðalmyndum um fólk með proskahömlun má álykta að GÆS hafi átt pátt í að opna umræðuna um dugnað og hæfileika fólks með proskahömlun og átt pátt í að breyta viðhorfum til hópsins.

Efnisord: Fólk með proskahömlun, atvinnupátttaka, mannréttindi, orðræða, fötlunarfræði.

\section{Inngangur}

Atvinna hefur mikil áhrif á sjálfsmynd fólks, hún er visst stöðutákn og mikilvægi atvinnu er jafn mikið fyrir jaðarsetta hópa samfélagsins og aðra. Niðurstöður rannsókna benda auk pess til að jafn mikilvægt sé fyrir fólk með proskahömlun og annað fólk að fá tækifæri til að vinna sig upp i starfi og axla ábyrgð. Einnig vill pað fá að ákveða sjálft hvaða störf pað vinnur, en svo virðist að oft fái fólk með proskahömlun ekki tækifæri til slíkra ákvarðana (Margrét Magnúsdóttir, 2010; Wistow og Schneider, 2003). Atvinnutækifæri fólks með proskahömlun á almennum vinnumarkaði hafa í gegnum tíðina verið takmörkuð og oft hafa pví einungis boðist lágt launuð hlutastörf með litlum möguleikum á stöðuhækkun eða starfsframa (Guðrún V. Stefánsdóttir, 2013; Hagner, 2000). Раð urðu pví ákveðin tímamót í atvinnupátttöku fólks með proskahömlun pegar kaffihúsið GÆS var opnað í Tjarnarbíói í júní 2013. Í fyrsta skipti á Íslandi stofnaði fólk 
með proskahömlun fyrirtæki, var í forsvari fyrir pað og sá um rekstur pess.

Mannréttindi fatlaðs fólks hafa verið í umræðunni á síðustu árum og áhrif samnings Sameinuðu pjóðanna um réttindi fatlaðs fólks (2013) hafa verið mikil. Samningurinn var fullgiltur af íslenskum stjórnvöldum árið 2016 og unnið er að innleiðingu hans hér á landi. Samkvæmt samningnum er pað á ábyrgð stjórnvalda að tryggja mannréttindi og pátttöku fatlaðs fólks á öllum sviðum samfélagsins. Í 27. grein samningsins eru réttindi fatlaðs fólks til atvinnu á almennum vinnumarkaði sérstaklega viðurkennd. Í greininni kemur fram að fötluðu fólki beri að fá tækifæri til að vinna krefjandi verkefni eins og til dæmis að stofna fyrirtæki (Samningur Sameinuðu pjóðanna um réttindi fatlaðs fólks, 2013). Бó svo að pað sé skylda stjórnvalda að vinna eftir samningi pessum sýna nýlegar íslenskar rannsóknir að atvinnutækifæri á almennum vinnumarkaði eru af skornum skammti og algengt er að viðhorf til fatlaðs fólks litist af fordómum og vantrú á getu pess (Félagsvísindastofnun Háskóla Íslands, 2011; Guðrún V. Stefánsdóttir, 2013; Velferðarráðuneytið, 2013).

Rannsóknin sem hér er til umfjöllunar hafði pað að markmiði að draga fram og greina pá orðræðu sem skapaðist í samfélaginu um kaffihúsið GÆS en pað hlaut mikla umfjöllun á fréttaog vefmiðlum. Sérstaklega var rýnt í hvernig ríkjandi orðræða um fólk með proskahömlun birtist. Auk pess var leitast við að fá fram á hvaða hátt orðræðan um GÆS mótaði reynslu stofnfélaganna fimm.

Leitast var við að svara eftirfarandi rannsóknarspurningum:

1. Hvað einkenndi orðræðuna um kaffihúsið GÆS og hverjar voru helstu pversagnirnar í henni?

2. Með hvaða hætti mótaði orðræðan um GÆS reynslu stofnfélaganna fimm?

Dað skal tekið fram að fyrsti höfundur greinarinnar vann með hópnum frá upphafi GÆSar, fyrst sem kennari og leiðbeinandi hópsins og síðan sem aðstoðarkona og rannsakandi eftir að kaffihúsið var opnað. Hlutverk hennar var að leiðbeina hópnum, aðstoða við að koma kaffihúsinu á fót og stuðla að pví að fimmmenningarnir yrðu sjálfstæðir kaffihúsarekendur sem væru í forsvari fyrir kaffihúsið og allt ferlið, frá hugmynd að veruleika.

\section{Fræðilegur bakgrunnur}

Sú rannsókn sem hér er til umfjöllunar er á sviði fötlunarfræða sem hafnar og mótmælir einhliða læknisfræðilegum skilningi á fötlun og leggur áherslu á félagslegan skilning á fötlun og mannréttindi (Hanna Björg Sigurjónsdóttir, Ármann Jakobsson og Kristín Björnsdóttir, 2013; Shakespeare, 1998). Fræðilegur bakgrunnur rannsóknarinnar byggist auk pess á kenningum Nine Lykke (2010) um samtvinnun, hugmyndum um ableisma, kenningum Michel Foucault um vald, orðræðu og heterótópíu (Oliver, 1990; Foucault, 1998, 2002, 1966-1976/2005; Goodley, 2011; Jón Ingvar Kjaran og Ingólfur Ásgeir Jóhannesson, 2015; Shildrick, 2017). Auk pess verður stuðst við rýmiskenningar de Certeau (1984).

Orðræða um fólk með proskahömlun hefur lengi litast af læknisfræðilegum skilningi á fötlun og meðal annars viðhaldið peirri sýn að pað sé byrði á fjölskyldum sínum og samfélagi og háð góðmennsku annarra til að geta spjarað sig í samfélaginu (Hanna Björg Sigurjónsdóttir, 2008; Kristin Björnsdóttir og Kristín Stella L'orange, 2014). Dessi orðræða og pau viðhorf sem birtast 1 henni hafa haft áhrif á félagslega stöðu, réttindi og daglegt líf fólksins (Rannveig Traustadóttir,v2006). Í kjölfar réttindabaráttu fatlaðs fólks á sjöunda og áttunda áratug liðinnar aldar og 1 andstöðu við læknisfræðilegan skilning á fötlun varð til róttækur félagslegur skilningur á fötlun. Félagslegur skilningur beinist að pví að greina samfélagslegar hindranir í lífi og umhverfi fatlaðs fólks sem er rauður práđur í rannsókn pessari. Dví er hafnað að fötlun orsakist einungis 
af skerðingu einstaklingsins heldur verði hún til vegna samfélagslegra hindrana og viðhorfa sem mótast hafa í gegnum sögu og menningu (Hanna Björg Sigurjónsdóttir o.fl., 2013). Með tilkomu samnings Sameinuðu pjóðanna um réttindi fatlaðs fólks hefur félagslegur mannréttindaskilningur á fötlun hlotið aukna athygli og viðurkenningu. Samkvæmt honum á fatlað fólk rétt á að njóta fullra mannréttinda og halda mannlegri reisn sinni. Litið er svo á að stjórnvöld beri ábyrgð og pað sé peirra að bregðast við hindrunum sem á vegi fatlaðs fólks verða, í pví skyni að fólk geti lifað lífi sínu með peirri reisn sem pað á rétt á og tekið fullan pátt í samfélaginu (Hanna Björg Sigurjónsdóttir o.fl., 2013). Sá skilningur á fötlun sem liggur að baki rannsókninni er auk félagslegs mannréttindaskilnings á fötlun svonefndur félagslegur tengslaskilningur á fötlun. Í honum er litið svo á að fötlun verði til í flóknu samspili líffræðilegra, menningarlegra og pólitískra pátta (Shakespeare, 2006; Tøssebro, 2004). Tengslaskilningur á fötlun er lagður til grundvallar í samningi Sameinuðu pjóðanna um réttindi fatlaðs fólks (2013).

Í rannsókninni er auk pess byggt á feminískum kenningum um samtvinnun sem hefur verið skilgreind sem fræðilegt tæki til pess að skoða og greina valdamisræmi í samfélaginu. Með pessum kenningum er hægt að skoða og greina hvernig félagslegar hugsmíðar eins og kyngervi, hörundslitur, stétt og kynhneigð geta stuðlað saman að pví að skapa og viðhalda félagslegu misrétti (Lykke, 2010). Рað var pó ekki fyrr en á allra síðustu árum að farið var að tengja fötlun í pessa umræðu og bent hefur verið á að pó að fötlun hafi ein og sér mikil áhrif á samfélagslega stöðu manneskjunnar tilheyrir fatlað fólk einnig öðrum hópum samfélagsins hvað varðar kyn, aldur, kynhneigð, etnískan uppruna, efnahagsstöðu, litarhátt o.s.frv. (Campell, 2009). Í samhengi samtvinnunar hefur verið bent á að fötlun geti líkt og kyngervi og hörundslitur haft áhrif á pað hvernig komið er fram við fatlað fólk í samfélaginu (Rannveig Traustadóttir, 2006).

Auk áðurnefndra hugmynda og kenninga um fötlun er rannsóknin undir áhrifum krítískrar fötlunarfræði (e. critical disability studies) en hún tengist öðrum krítískum fræðum eins og hinsegin fræðum og feminískum fræðum. Dannig vísar hugtakið fötlun til ákveðinnar félagslegrar undirokunar og misréttis sem líkt er við kynpáttamisrétti og kynjamisrétti svipað og kenningar um samtvinnun gera rád fyrir. Ráðandi staða ófatlaðs fólks í samfélaginu hefur í för með sér mikið valdamisræmi. Samkvæmt krítíska sjónarhorninu er mikilvægt að fatlað fólk stígi fram, skipi sér sess og andæfi valdi hins ófatlaða meirihluta (Goodley, 2014). Innan krítískra fötlunarfræða hefur hugtakið ableismi verið notað til að greina viðhorf og fordóma gagnvart fötluðu fólki en jafnframt til að draga fram valdaaðstæður innan samfélags sem hyglir peim sem eru ófatlaðir. Ableismi gengur út frá pví að fötlun sé ákveðið frávik frá norminu og að ófatlað fólk sé alltaf sett skör hærra en fatlað fólk í samfélaginu. Samfélagið sé pví skipulagt út frá ófötluðu fólki og ekki gert rád fyrir hvers kyns margbreytileika (Carlson, 2001; Goodley, 2011; Shildrick, 2017). Petta má til dæmis heimfæra á pað pegar ekki er gert ráð fyrir að fólk með proskahömlun geti stofnað og rekið sitt eigið fyrirtæki. Í rannsókninni er hugtakið notað til pess að varpa ljósi á hversu margslungin, rótgróin og flókin viðhorf til fólks með proskahömlun geta verið.

Í rannsókninni er byggt á orðræðugreiningu í anda franska heimspekingsins Michel Foucault (1998, 1966-1976/2005). Аð hans mati er tiltekin orðræða ríkjandi á hverjum tíma pó svo að birtingarmyndir hennar geti verið mismunandi. Orðræðu má skilgreina sem samspil pekkingar og valds sem bæði ákvarðar hvernig eigi að orða hlutina, hverjir megi segja hvað og í hvaða samhengi. Ríkjandi orðræða hefur pví mótandi áhrif á hugmyndir fólks og á hvað sé viðurkennt hverju sinni. Dannig eru bein tengsl á milli pekkingar og valds sem móta viðhorf fólks til sjálfs síns og annarra. Orðræða getur par af leiðandi breitt út og styrkt ríkjandi hugmyndir innan samfélagsins, hyglað með öðrum orðum tilteknum valdahópum. Svo dæmi sé tekið pá hefur orðræða um fólk með proskahömlun í sögulegu samhengi verið á valdi ófatlaðs fólks og hefur haft mikil áhrif á félagsleg viðhorf til hópsins (Campell, 2009). Með pví að rýna í orðræðuna má pví draga fram valdaafstæður og hvernig viðhorf til ákveðinna jaðarhópa hafa próast og orðið að ríkjandi pekkingu sem að mati Foucault (1966-1976/2005) getur leitt til útilokunar og jaðarsetningar. Allt sem fellur utan hins ríkjandi viðmiðs verður að mati Foucault (1998, 19661976/2005) afbrigðilegt og um leið óæskilegt. Slík aðgreining getur verið sérstaklega skaðleg 
jaðarsettum hópum sem oft fá ekki tækifæri til að andæfa valdinu. Hins vegar vekur allt vald að mati Foucault upp andóf gegn ríkjandi hugmyndum. Svo dæmi sé tekið pá mætti nefna andóf og gagnrýni gegn manngerðum hindrunum í samfélaginu eða ákveðinni orðræðu um fatlað fólk. Markmið orðræðugreiningar er pví að draga fram ólíkar birtingarmyndir og pversagnir í orðræðunni. Dversagnirnar eru pannig hluti af orðræðunni og með peim er oft hægt að finna andóf gegn pví sem er ríkjandi í menningunni hverju sinni (Ingólfur Ásgeir Jóhannesson, 2006).

Michel de Certeau (1984) gerir grein fyrir ákveðnum mun á stöðum og rými. Ríkjandi öfl hafa valdið í skipulagningu á stöðum í samfélaginu og par ríkir ákveðinn stöðugleiki, röð og regla. Pó að ríkjandi hópar hafi par völdin pá eru staðirnir líka notaðir af jaðarsettum hópum samfélagsins. Með hugtakinu rými er átt við bæði hlutlægt og huglægt svæði innan staða og í menningu fólks. Rýmið getur líka verið ákveðið andrými og pannig rými jaðarsettra hópa. Viðhorf og framkoma ríkjandi afla hafa áhrif á hvernig rými próast og dafna. Pannig ná pau að viðhalda félagslegum yfirburðum sínum og menningu (Lefebvre, 1991). Fatlað fólk sem jaðarsettur hópur parf oft að skapa sér rými með fjölbreyttum, óhefðbundum og skapandi aðferðum sem eru pá í andstöðu við hugmyndir ríkjandi hópa (Kristín Björnsdóttir og Ingólfur Ásgeir Jóhannesson, 2013). de Certeau (1984) talar um aðferð pegar farið er á móti straumnum og ekki farið eftir settum reglum eða pegar fólk kemur fram á annan hátt en ætlast er til. Samkvæmt rýmiskenningum de Certeau pá má segja að vettvangur kaffihúsa í Reykjavík sé dæmi um staði. Innan hennar gilda ákveðnar reglur um kaffihúsarekstur, bæði skráðar og óskráðar. Ein af óskráđu reglunum er sú að kaffihúsum sé stýrt af ófötluðu fólki. Degar GÆS var stofnað bjuggu pau sem að kaffihúsinu komu sér til sitt eigið rými innan pess vettvangs sem kaffihús í Reykjavík eru, rými par sem pau höfðu valdið, voru metin að verðleikum og gátu haft áhrif á bæði samfélagið og orðræðuna um sig. Rýmiskenningar de Certeau eru notaðar í pví skyni að varpa ljósi á sérstæði rýmis GÆSar og áhrifamátt pess.

Hugtakið heterótópía fellur vel að rýmishugmyndum de Certeau en Foucault skilgreindi pað sem rými pess óhefðbundna eða sem annars konar rými, jafnvel rými í rýminu eða eins konar hliðarrými (Foucault, 2002). Í heterótópíu eru gjörðir fólks oft undir öðrum reglum en peim sem pað undirgengst í sínu venjubundna lífi/rými. Foucault velti fyrir sér ýmsum tegundum af heterótópíum, m.a. heterótópíum sem rými fyrir hópa á jaðrinum, pá sem falla ekki að ríkjandi normi samfélagsins. Í samfélagi fólks og menningu er pað ríkjandi norm að vera ófatlaður og í vinnu á almennum vinnumarkaði. Í pví sambandi er hægt að nýta sér heterótópíuhugtak Foucault pegar „hliðarrými“ á borð við GÆS er skoðað og greint, en par fengu pátttakendur rannsóknarinnar tækifæri til að blómstra og móta sig í störfum sem fram til pessa höfðu verið álitin vera fyrir ófatlað fólk. Par með getur pess háttar rými talist frelsandi (Jón Ingvar Kjaran og Ingólfur Ásgeir Jóhannesson, 2015).

\section{Аðferð}

Rannsóknin sem hér er til umfjöllunar er etnógrafísk rannsókn sem flokkast til eigindlegra rannsóknaraðferða. Etnógrafía á rætur sínar að rekja til mannfræðirannsókna en hefur líka öðlast sess í félags- og menntavísindum. Markmið etnógrafískra rannsókna er að leitast við að skilja sjónarhorn fólks í náttúrulegum aðstæðum pess. Í etnógrafískum rannsóknum er sjónum oft beint að pví sem á yfirborðinu er ósýnilegt og parfnast fjölbreyttra leiða til að skoða. Etnógrafía felur í sér fjölbreytta nálgun og einkennist meðal annars af pátttökuathugunum og viðtölum við gagnasöfnun sem fellur vel að peirri rannsókn sem hér er til umfjöllunar par sem rannsóknin samanstendur meðal annars af viðtölum og pátttökuathugunum svo og að lykilpátttakendur tóku pátt í mótun hennar (Atkinson og Hammersley, 2007). 


\section{Pátttakendur}

Lykilpátttakendur í verkefninu voru fjórar konur og einn karlmaður. Dau voru öll nemendur í starfstengdu diplómanámi fyrir fólk með proskahömlun. Pau tóku sjálf ákvörðun um að taka pátt í kaffihúsahópi í starfsnámi sínu og völdust pannig í rannsóknina. Kaffihúsaverkefnið GÆS er pjóðpekkt, hlaut mikla umfjöllun í fjölmiðlum eins og fram hefur komið og fimmmenningarnir vilja öll koma fram undir nafni. Dau eru Gísli Björnsson, Lára Steinarsdóttir, María D. Hreiðarsdóttur, Steinunn Ása Dorvaldsdóttir og Unnur Jónsdóttir. Dað er ekki venjan að nefna pá sem taka pátt í rannsóknum með nafni en hjá pví verður ekki komist par sem að GÆS er pjóðpekkt. Auk pess eru pau stolt af pátttöku sinni í GÆS og vilja koma fram undir nafni. Pau eru hins vegar ekki nefnd á nafn í umfjöllun um niðurstöður í greininni og pví er ekki hægt að rekja einstök ummæli til hvers og eins peirra. Nánar verður fjallað um petta í kafla um siðferðileg álitamál.

\section{Gagnasöfnun og greining}

Rannsóknin var unnin í tveimur hlutum. Annars vegar voru tekin tíu einstaklingsviðtöl og tólf rýnihópaviðtöl við frumkvöðlana fimm, p.e. GÆSarhópinn. Fyrsti greinarhöfundur fylgdist jafnframt með öllu ferlinu og vann pátttökuathuganir. Hins vegar voru fjölmiðlaumfjöllun og gögn af samfélagsmiðlum greind með sögulegri orðræðugreiningu í anda Michel Foucault par sem leitað var eftir prástefjum í textanum (Foucault, 1972; Ingólfur Ásgeir Jóhannesson, 2006).

Tilgangur rýnihópaviðtalanna var að ræða hugmyndir og reynslu pátttakenda af starfi sínu á GÆS. Rýnihópaviðtöl hentuðu hópnum vel og oftast leiddu pau til pess að skilningur varð á milli allra sem tóku pátt. Dað var pó mikilvægt að fara af stað með ákveðið og skýrt viðfangsefni til að ræða sem oft tók svo óvænta stefnu í takt við umræðurnar hverju sinni (Silverman, 2010). Tilgangur einstaklingsviðtalanna var að öðlast betri skilning á reynslu fimmmenninganna. Markmið peirra var að fá fram sjónarhorn peirra og gefa peim tækifæri til að ræða reynslu sína af pátttöku sinni í GÆS. Með einstaklingsviðtölum var líka hægt að dýpka margt sem áður hafði komið fram í rýnihópaviðtölum og var meira við hæfi að ræða í einrúmi. Undirbúningur fyrir rýnihópa- og einstaklingsviðtöl fólst meðal annars í pví að búa til lista yfir ákveðin atriði. Dessi listi varð síðan að opnum viðtalsramma sem var í próun gegnum öll viðtölin. Dannig skapaðist flæði í umræðunum og hægt var að fylgja spurningum betur eftir í takt við hvernig umræðan próaðist. Öll viðtöl voru hljóðrituð, afrituð og greind með einfaldri pemagreiningu (Creswell, 2007). Viðtölin voru tekin á árunum 2012-2014, ýmist á heimilum pátttakenda, í húsnæði Menntavísindasviðs eða á kaffihúsinu GÆS. Í pátttökuathugunum fólst að fyrsti greinarhöfundur fylgdist með lykilpátttakendum í öllu ferlinu og eftir að kaffihúsið var opnað. Hún varði alls 170 tímum á vettvangi og eftir hvern dag skrifaði hún vettvangsnótur par sem lýst var aðstæðum, samskiptum og pví sem átti sér stað. Við undirbúning gagnagreiningarinnar var skipulagi komið á gögnin, peim raðað upp pannig að pau væru aðgengileg og að sem auðveldast væri að hafa yfirsýn yfir pau. Leitað var eftir síendurteknum hugmyndum og athöfnum sem birtust í samtölum og frásögnum pátttakenda og skoðað var hvernig frásagnirnar mynduðu heilsteypta lýsingu á pví hvernig viðmælendur upplifðu ákveðin atriði og petta tímabil (Braun og Clarke, 2013). Í greiningu á einstaklingsviðtölum, rýnihópaviðtölum, pátttökuathugunum og dagbókum/ vettvangsnótum rannsakanda urðu til prjú meginpemu: Nýsköpun, viðhorf og pakklæti.

Fjölmiðlaumfjöllun og gögn af samfélagsmiðlum voru greind með sögulegri orðræðugreiningu 1 anda Michel Foucault par sem leitað var eftir prástefjum í textanum. Drástefin eru hugmyndir sem birtast endurtekið í texta. Skoðað var hvort prástefin mynduðu mynstur í orðræðunni. Með orðræðugreiningu er leitast við að greina mismunandi sjónarhorn og pversagnir (Foucault, 1972; Ingólfur Ásgeir Jóhannesson, 2006). Fyrirliggjandi gögn voru tíu blaðagreinar í Fréttablađinu, DV (Dagblaðið Vísir) og Morgunblaðinu og fréttir sem birtust á Ruv.is á tímabilinu apríloktóber 2013. Auk pess voru Facebook-síða GÆSar greind. Dessir miðlar voru valdir vegna pess að sú orðræða sem par er að finna lýsir hvað best umræðunni í samfélaginu. Í greiningunni 
urðu prástefin prjú: Nýsköpunarorðræða, félagsleg og menningarleg orðræða og hetju- og góðgerðaorðræða. Í niðurstöðukafla pessarar greinar verður fjallað um pemu og orðræðu saman par sem petta tvennt kallast á.

\section{Siðferðileg álitamál}

Í eigindlegum rannsóknum er talið mikilvægt að rannsakendur séu sér meðvitaðir um tengsl sín við rannsóknarefnið og geri grein fyrir peim (Creswell, 2007). Fyrsti höfundur kenndi, var leiðbeinandi og samstarfskona GÆSarhópsins frá hugmynd pess að veruleika. Dað var pví mikilvægt í öllu ferlinu að ígrunda eigin viðhorf og sjónarmið og skoða með hvaða hætti pau höfðu áhrif á framvindu rannsóknarinnar og niðurstöður hennar. Fyrsti höfundur tók pann pól í hæðina frá upphafi að GÆS væri verkefni peirra og að hennar hlutverk væri að ýta undir sjálfstæði hópsins, undirbúa hann vel pannig að pátttakendur gætu axlað ábyrgð á GÆS eftir að náminu lauk. GÆS var pví alltaf kaffihúsið peirra, hugmyndin kom úr peirra röðum og allur undirbúningur og vinna fólst í pví að styrkja pá í pessu nýja hlutverki.

Í siðferði rannsókna er mikilvægt að pátttakendur séu sáttir við sitt framlag og að rannsóknin verði peim ekki til skaða. Litið er svo á að upplýst sampykki sé lykilatriði í siðferði rannsókna. Pátttakendur í rannsókninni fengu upplýsingar um hana í upphafi og skrifuðu undir sampykkiseyðublað par sem fram kom að peir gætu hætt pátttöku hvenær sem væri (Esterberg, 2002). Frá upphafi rannsóknarinnar komu lykilpátttakendur að ákvarðanatöku í sambandi við rannsóknina og vinnslu hennar. Í eigindlegum rannsóknum er nafnleynd talin skipta miklu máli. Auk pess er mikilvægt að rannsakandi sýni pátttakendum virðingu og sé peim og rannsókninni trúr (Bogdan og Biklen, 1998). Fjallað hefur verið um GÆS opinberlega og pví ekki mögulegt að tryggja nafnleynd lykilpátttakenda. Auk pess vilja peir koma fram undir nafni, eru stoltir af pátttökunni í GÆS og finnst ekki við hæfi að koma fram undir dulnefni. Komist var að peirri niðurstöðu að peir yrðu nafngreindir í pessum kafla um aðferðafræði í greininni en ekki að öðru leyti. Dannig er ekki hægt að tengja ákveðin atriði og ummæli við hvert og eitt peirra. Dessi staða er að einhverju leyti óvenjuleg í rannsóknum á pessu sviði enda alltaf lögð áhersla á persónuvernd og að pátttakendur skaðist ekki á neinn hátt vegna pátttöku sinnar (Bogdan og Biklen, 2003).

\section{Gildi rannsóknar}

Niðurstöður rannsóknarinnar hafa ákveðið nýsköpunargildi en verkefnið varð til í grasrót fólks með proskahömlun og á sér ekki hliðstæðu hér á landi. Par má sérstaklega nefna pá sérstöðu að fólk með proskahömlun sé við stjórn og rekstur fyrirtækis sem telst nýlunda hérlendis. Í Bandaríkjunum eru nokkur dæmi pess að fólk með proskahömlun sé í fyrirtækjarekstri og má par nefna sokkafyrirtæki, brauðgerð og rekstur veitingahúsa (Aol, 2013; John's crazy socks, 2017). Hagnýtt gildi rannsóknarinnar felst ekki síst í pví að læra af pví ferli sem fór fram og reyna að skilja hvað liggur að baki orðræðunni um kaffihúsið GÆS. Ef neikvæð viðhorf eru ekki afhjúpuð og rædd pá munu pau ekki breytast. Niðurstöður pessarar rannsóknar munu pví geta átt pátt í pví að breyta viðhorfum og mögulega vinnubrögðum í málaflokki fatlaðs fólks sem oft er ekki nægilega mannréttindamiðaður.

\section{Bakgrunnur - kaffihúsið GÆS}

Hugmyndin að kaffihúsinu GÆS varð til í diplómanámi fyrir fólk með proskahömlun við Menntavísindasvið Háskóla Íslands. Diplómanámið er starfstengt og um pað bil helmingur námsins er vettvangstengdur en undirbúningur og framkvæmd kaffihússins var hluti af starfsnámi fimm nemenda í diplómanáminu. Hugmyndina að kaffihúsinu GÆS fékk Steinunn Ása Porvaldsdóttir en haustið 2011, er hún hafði nýhafið diplómanám sitt, kom hún að máli við fyrsta höfund greinarinnar sem starfaði sem verkefnastjóri diplómanámsins og sagði: „Баð eru of fá atvinnutækifæri fyrir fatlað fólk, pví vil ég breyta og opna mitt eigið kaffihús. Get ég 
gert pað í náminu?“ Eftir mikla undirbúningsvinnu varð til nýstárlegt verkefni sem tengdist atvinnupátttöku diplómanema og meistaraverkefni pví sem hér er til umfjöllunar. Í hönd fóru spennandi tímar við að próa verkefnið, móta hugmynd pess og finna leiðir til að pað gæti orðið að veruleika.

Á fyrstu stigum verkefnisins var leitað til Reykjavíkurborgar sem sýndi verkefninu áhuga og veitti pví styrk til að hefja starfsemina. Dví næst veitti Háskóli Íslands leyfi fyrir verkefninu, að fyrsti höfundur leiddi starfsnámshóp diplómanema og leiðbeindi í öllu ferlinu. Á vormisseri 2013 varð starfsnámshópurinn og kaffihúsaverkefnið GÆS að veruleika. Eins og áður sagði völdust fimm nemendur úr diplómanáminu í hópinn og hlutverk peirra var að móta hugmyndafræði GÆSar ásamt pví að gerast sérfræðingar í kaffihúsarekstri. Рað var meðal annars gert með pví að fara í starfspjálfun hjá fyrirtækinu Kaffitári, heimsækja fjöldann allan af kaffihúsum, fá fræðslu í rekstri, vera í hugmyndavinnu, innrétta kaffihúsið, ákveða matseðil, vera í samstarfi við Kaffitár svo og Reykjavíkurborg og sækja fundi með fulltrúum borgarinnar, markaðssetja fyrirtækið, finna pví nafn, finna hentugt húsnæði, hanna vörumerki (lógó) og margt fleira. Nafn kaffihússins GÆS stendur fyrir einkunnarorð GÆSarhópsins - get-ætla-skal. Nafnið pótti líka lýsandi fyrir staðsetningu kaffihússins sem stóð við Reykjavíkurtjörn par sem stór gæsahópur heldur til. Kaffihúsið GÆS var opnað í júní 2013 eftir langt og strangt undirbúningstímabil og var rekið sumarið 2013 með styrk frá Reykjavíkurborg og Háskóla Íslands með möguleika á að halda áfram rekstri ef vel tækist til. Haustið 2013 var kaffihúsinu lokað pví að ekki náđist samkomulag á milli GÆSarhópsins og Reykjavíkurborgar um frekara samstarf. Kaffihúsið var opnað á ný sumarið 2014 og starfaði pá um sumarið í litlu húsi á Bernhöftstorfu. Að auki hefur hópurinn tekið pátt í jólamarkaði á Ingólfstorgi og jafnréttisdögum Háskóla Íslands. GÆS hefur hlotið margvíslega viðurkenningu og hafa stofnfélagarnir víða haldið fyrirlestra um verkefnið. Dau hlutu Múrbrjót Landssamtakanna Proskahjálpar árið 2013 fyrir nýsköpun í atvinnumálum og hvatningarverðlaun Öryrkjabandalags Íslands sama ár.

\section{Niðurstöður}

Dessi kafli fjallar um niðurstöður rannsóknarinnar og skiptist í prjá undirkafla sem eru: Nýsköpun, fyrirmyndir og frumkvöðlastarf, Staðalmyndirnar krakkar, hetjur og 2000 bollar af pakklæti og Örlög GÆSar.

\section{Nýsköpun, fyrirmyndir og frumkvöðlastarf}

Í kjölfar pess að kaffihúsahópurinn GÆS opnaði síðu á Facebook á vordögum 2013 varð mikil umfjöllun um verkefnið í fjölmiðlum. Sem dæmi má nefna að hópurinn fór í tuttugu viðtöl árið 2013 en auk viðtala í byrjun hélt fjölmiðlaumfjöllunin áfram eftir að GÆS var opnað. Fjallað var um verkefnið í dagblöðum, sjónvarpi og útvarpi og daginn sem GÆS hóf starfsemina var fjallað um opnunina í kvöldfréttum ríkissjónvarpsins. Í upphafi beindist umfjöllunin að peirri nýlundu að fólk með proskahömlun væri í forsvari fyrir sitt eigið fyrirtæki. Fyrsta fréttin sem skrifuð var um GÆS birtist á forsíðu Fréttablaðsins 11. apríl 2013. Greinin bar yfirskriftina „Brautryðjendur sem undirbúa ævintýri“. Í fréttinni var fjallað um pá mannréttindasýn sem GÆS stendur fyrir og að petta væri í fyrsta sinn á Íslandi sem fólk með proskahömlun stofnaði sitt eigið fyrirtæki. Fréttin var í viðtalsformi og par segir Steinunn Ása Porvaldsdóttir: „Fatlað fólk getur allt ef pað fær tækifæri til pess“" (Garðar Örn Úlfarsson, 2013). Sambærileg umfjöllun kom fram í flestum fréttamiðlum landsins og fjallað var um hópinn sem að kaffihúsinu kom sem frumkvöðla og fyrirmyndir. Mikil jákvæðni og bjartsýni einkenndi pá nýsköpunarorðræðu sem fram fór í fjölmiðlum. Í fréttaflutningi kom ítrekað fram að hugmyndin að kaffihúsinu hefði orðið til í röðum frumkvöðlanna fimm. Opinbera orðræðan um GÆS varð til pess að hópurinn fékk ótakmarkað aðgengi að fjölmiðlum og keppst var um að fjalla um pau sem hlut áttu að máli og kaffihúsið peirra. Sú umfjöllun varð svo mikil að á tímabili fóru pau að eigin frumkvæði í tímabundið fjölmiðlabann. Petta hafði eitt peirra um málið að segja: 
Detta var bara orðið of mikið, við vorum alltafí viðtölum og við vildum ekki að allir væru bara orðnir preyttir á okkur áður en GÆS opnaði. Pess vegna fórum við í fjölmiðlabann.

Hópurinn hafði pá farið í átta viðtöl í hinum ýmsu fjölmiðlum. Í pví sambandi má leiða að pví líkur að „rýmið GÆS“ hafi orðið til pess að hópurinn öðlaðist nýja rödd og að á pau væri hlustað. Til pess að búa til rýmið GÆS purfti hópurinn að fara óhefðbundnar leiðir par sem GÆS varð til í starfsnámi, fékk styrki til pess að hefja starfsemina og hafði ekki yfir miklu fjármagni að ráða. Dau purftu að vekja athygli á verkefninu sem varð til pess að allir fjölmiðlar vildu fjalla um GÆS og er pað sennilega best kynnta kaffihús sem opnað hefur verið á Íslandi. de Certeau (1984) bendir á að jaðarsettir hópar samfélagsins purfi oft að fara óhefðbundnar leiðir rétt eins og GÆSarhópurinn gerði. Rýmið var í raun tvenns konar, pað rými sem GÆS fékk í fjölmiðlum og svo sjálft rýmið kaffihúsið GÆS sem var pá forsenda fyrir fjölmiðlarýminu. Rými kaffihússins GÆSar var óvænt, óhefðbundið, bjart og skemmtilegt og segja má að manngerðum hindrunum eins og staðalmyndum sem felast í að draga fram vangetu fólks með proskahömlun hafi verið ögrað. Hópnum voru allir vegir færir. GÆS var peirra rými sem pau vildu stolt sýna almenningi. Dau fundu að pau gátu haft áhrif og sýnt hvað í peim bjó:

Mér fannst svo gaman hvað allir höfðu mikinn áhuga á GÆSinni okkar, pað voru allir alltaf að spyrja mig. GÆS var líka svo flott. Pað var líka gaman að sýna öllum að fatlaðir geta ýmislegt, við purfum bara að fá tækifæri og pá getum við sýnt pað.

Með pessum hætti varð GÆS frelsandi rými, hliðarrými eða nokkurs konar heterótópía, par sem fatlað fólk gat sjálft haft áhrif á orðræðuna um sig og á umræðuna. Fólk með proskahömlun hefur átt takmarkaðan aðgang að fjölmiðlum og pegar fjallað er um málefni pess er algengast að ófatlaðir sérfræðingar séu í pví hlutverki í stað pess að fólkið sjálft fái tækifæri til að tjá sig (Kristín Björnsdóttir, 2009). Sú mikla umfjöllun sem var um GÆS var pví um margt óvanaleg í sögulegu samhengi. Рað má pví leiða að pví líkur að með GÆS hafi átt sér stað ákveðin vitundarvakning í íslensku samfélagi um getu og hæfileika fólks með proskahömlun og að pað geti lagt mikilvæga hluti til samfélagsins. Í 8. grein samnings Sameinuðu pjóðanna um réttindi fatlaðs fólks er vakin athygli á mikilvægi vitundarvakningar með pað að markmiði að auka virðingu fyrir réttindum fatlaðs fólks og breyta neikvæðum viðhorfum. Par kemur líka fram að ábyrgð fjölmiðla sé mikil og að hvetja skuli fjölmiðla til að fjalla um fatlað fólk af virðingu og á jákvæðan hátt (Samningur Sameinuðu pjóðanna um réttindi fatlaðs fólks, 2013). Viðhorfum má breyta og bent hefur verið á að árangursríkast hafi reynst pegar fatlað fólk á sjálft pátt í breytingum með pví að tjá sig og láta rödd sína heyrast (Eva Pórdís Ebenezersdóttir, 2014) eins og GÆSarhópurinn sýndi. GÆSarfólkið var líka meðvitað um hvernig pað vildi að fjallað væri um hópinn, hvaða hugtök væru notuð og létu fréttafólk og blaðamenn vita af pví. Ýmist notaði hópurinn Facebook-síðu GÆSar eða skrifaði tölvupóst til fréttamanna og pau hikuðu ekki við að gera viðvart ef peim pótti orðalag vera meiðandi eða ekki við hæfi. Til dæmis var GÆS í einu viðtali kallað kaffihús fatlaðra (Kaffihús fatlaðra fær verðlaun, 2013). Dá var hópurinn fljótur að bregðast við og minna á að GÆS væri staður fyrir alla en ekki aðgreinandi rými. Pannig gátu pau haft áhrif á orðræðuna um sig og haldið uppi ákveðnu andófi. Rýmið var pannig frelsandi fyrir hópinn og staður til að hafa áhrif.

Einkenni peirrar nýsköpunarorðræðu sem fram kom um GÆS var auk pess ákveðin bjartsýni og jákvæðni. Hvert sem félagarnir í hópnum komu var peim vel tekið og allir vildu tala um GÆS. Pannig var GÆS til umfjöllunar á mörgum stöðum í samfélaginu, ekki aðeins á Facebook heldur til dæmis líka í heitu pottunum en par fer oft fram lifandi samfélagsumræða og speglar hún ekki síður íslenskt samfélag. Petta kom fram í vettvangsnótum fyrsta höfundar daginn eftir sjónvarpspáttinn Kastljós par sem GÆSarhópurinn var í aðalhlutverki 19. apríl 2013:

Í dag var einstaklega gaman að vera með GÆS, við fórum í heimsókn á kaffihús og par var hópnum vel tekið. Par eins og alls staðar vildu allir tala um GÆS, par kom fram að GÆS hefði verið aðalumræðuefnið í heitu pottunum í Vesturbæjarlaug pennan morguninn. Dar fögnuðu allir framtakinu og hrósuðu GÆSarhópnum fyrir frábært framtak. 
Áhrif nýsköpunarorðræðunnar voru pví mikil og reyndust frelsandi fyrir hópinn. Hún gaf félögunum byr í seglin í upphafi og lét pau finna að kaffihúsið GÆS væri velkomið. Auk pess reyndist umræðan rós í hnappagat Reykjavíkurborgar sem styrkti reksturinn frá upphafi.

\section{Staðalmyndirnar krakkar, hetjur og 2000 bollar af pakklæti}

Í aðdraganda opnunar kaffihússins, pann 9. maí 2013, var haldin svokölluð bollasöfnun í ráðhúsi Reykjavíkur að frumkvæði Reykjavíkurborgar. Fréttablaðið var meðal peirra fjölmiðla sem fjallaði um bollasöfnunina og 1 frétt blaðsins var biðlað til almennings um að leggja verkefninu lið (Fólk beðið um að leggja til bolla, 2013). Söfnunin gekk vonum framar og rúmlega 2000 bollar söfnuðust. Á samfélagsmiðlum kom prástefið um gjafmildi Íslendinga ítrekað fram. Mun fleiri en peir sem komu á bollasöfnunardaginn vildu gefa bolla og aðra hluti sem að gagni gætu komið á kaffihúsinu. Raunin varð sú að GÆS fékk allt of mikið af hlutum sem engin not voru fyrir. Degar fólk fær hluti að gjöf er yfirleitt ætlast til að pað sýni pakklæti. Hópurinn var pví oft í pví hlutverki að purfa að pakka fyrir sig, telja upp pá sem gáfu og taka myndir af sér með peim sem gáfu. Баð má leiða að pví líkur að kaffihús sem rekið væri af ófötluðu fólki fengi tæplega sambærilega umfjöllun og gjafir og raun bar vitni. Ekki er ólíklegt að heimfæra megi pessa miklu gjafmildi á söguleg viðhorf í garð fólks með proskahömlun sem byggjast á peim viðhorfum að fólkið sé upp á góðmennsku og velvild annarra komið og að pað eigi að vera pakklátt (Guðrún V. Stefánsdóttir, 2008). Hópurinn var vissulega pakklátur fyrir allar pessar gjafir en fannst líka nóg um alla gjafmildina.

Dað var alveg ótrúlegt hvað við fengum mikið gefins. Við vissum samt ekkert hvað við áttum að gera við allt petta dót. Hvaðan kom petta eiginlega allt saman? Fólkið var nú voða gott að gefa okkur petta allt en við gátum ekkert notað petta allt.

Рað voru án efa mismunandi sjónarmið að baki gjöfunum og ætla má að margir hafi séð að parna væri verkefni sem vert væri að styðja, höfðu trú á pví og vildu veita kaffihúsinu brautargengi.

Í umfjöllun um GÆSarhópinn á samfélagsmiðlum komu fram ýmsar pversagnir sem heimfæra má á algengar staðalmyndir um fatlað fólk. Meðal annars má nefna að fólk með proskahömlun hefur verið sett 1 ýmis söguleg hlutverk eins og að pað sé eilíf börn, háð forræði og aðstoð annarra. Auk pess hefur fatlað fólk oft verið sett í hlutverk hetju, ofurhetju eða snillinga (Kristín Björnsdóttir, 2009). Ímynd hetjunnar eða ofurmennisins felst meðal annars í pví að fatlað fólk sigrast á fötlun sinni á einhvern hátt með pví að gera eitthvað sem ekki er vænst af pví (Kristín Björnsdóttir, 2006). Ekki er heldur óalgengt að fötluðu fólki sé hrósað fyrir hluti sem teljast sjálfsagðir pegar um ófatlað fólk er að ræða. Umfjöllunin um GÆS á samfélagsmiðlum endurspeglaði pessar staðalmyndir af fötluðu fólki. Pví var til dæmis lýst sem hetjum og dugnaðarforkum en jafnframt var talað um pað sem gleðigjafa, krakka eða krakkana. Hópnum var auk pess hrósað á samfélagsmiðlum fyrir hugmyndina að GÆS, framtakið, gleðina og hversu frábær pau væru. Prástefið stolt kom líka fram í pessari orðræðu og almenningur tjáði sig ítrekað um pað hve stoltur hann væri af GÆSarhópnum.

Рað vekur athygli í pessari umræðu að velgengni GÆSar virtist koma almenningi á óvart. Í pví sambandi má leiða að pví líkur að ákveðið vanmat á getu fólksins hafi áhrif sem á sér ekki síst rætur í skorti á tækifærum, en fólk með proskahömlun hefur í gegnum tíðina fengið fá tækifæri til að sanna sig á almennum vinnumarkaði (Johnson, 2005). Dví er ekki reiknað með að fólk með proskahömlun sé fært um að reka fyrirtæki eins og GÆS. Ekki er ólíklegt að almenningi hafi fundist að með framtakinu hafi hópurinn sigrast á fötlun sinni og náð óvenjulegum árangri og komist með peim hætti á sama stall og ófatlað fólk. Đó að almenningur samgleddist GÆSarhópnum og sýndi kaffihúsinu mikinn áhuga má draga pá ályktun að viðbrögðin og par með orðræða um GÆS hafi byggst á ableisma par sem gengið er út frá pví að fólk með proskahömlun geti ekki og eigi ekki að geta pað sama og ófatlað fólk. 


\section{Örlög GÆSar}

Eins og frá hefur verið greint ögraði kaffihúsið GÆS ríkjandi hugmyndum um fólk með proskahömlun, hugmyndum sem hafa meðal annars birst í vantrú á getu fólksins til að standa á eigin fótum (Guðrún V. Stefánsdóttir, Kristín Björnsdóttir og Ástríður Stefánsdóttir, 2014). Félagarnir í GÆSarhópnum gerðu sér fulla grein fyrir pví að pau voru frumkvöðlar í íslensku samfélagi og að pau höfðu með framtaki sínu haft áhrif á viðhorf almennings til fólks með proskahömlun. Ein úr GÆSarhópnum lýsti pessu pannig:

Bara hugmyndin að fólk með proskahömlun væri að sjá um sitt fyrirtæki breytti heilmiklu og fólk var forvitið um hvernig pað væri hægt.Við sýndum fólki að pað væri hægt. Mér fannst eins og að samfélagið hefði trú á okkur.

Auk pess að ögra ríkjandi hugmyndum um fólk með proskahömlun fannst GÆSarhópnum skipta máli að sýna að pau gætu staðið á eigin fótum og verið í forsvari fyrir eigið fyrirtæki. Dau voru sannfærð um að með pví að sýna getu sína myndi almenningur átta sig á að pau hefðu hæfileika og gætu pað sama og aðrir ef pau fengju tækifæri og réttan stuðning. Deim fannst mikilvægt að fá tækifæri til pess að vera sýnileg og pau voru stolt af pátttöku sinni í GÆS. Deim fannst samfélagið hafa trú á peim og að GÆS væri allra eins og titill pessarar greinar vitnar um. „GÆSin mín og GÆSin pín, Egils malt og appelsín,“ sagði einn af stofnfélögum GÆSar í góðu tómi og tengist pað peirri upplifun að kaffihúsið hafi verið okkar allra rétt eins og Egils malt og appelsín. Fimmmenningarnir vildu deila sinni lífssýn og rýminu á GÆS og peim fannst almenningur eiga hlutdeild í GÆS með peim. Drátt fyrir velgengni GÆSar og góðar viðtökur almennings hætti GÆS starfsemi sinni í Tjarnarbíói haustið 2013. Ástæðan fyrir pví var tvípætt. Annars vegar var sýn Reykjavíkurborgar önnur en GÆSarhópsins og fólst í pví að Reykjavíkurborg vildi ráða verkefnastjóra yfir kaffihúsinu sem hefði pað hlutverk að hafa yfirumsjón með pví og próa pað áfram og hins vegar misstu pau húsnæðið í Tjarnarbíó. GÆSarhópurinn var alfarið á móti pví að ráðinn yrði fyrir pau verkefnastjóri enda byggði hugmyndafræði GÆSar á pví að pau væru sjálf við stjórnvölinn. Ein úr GÆSarhópnum líkti pessari hugmynd við pað að ráđa forstöðukonu, en hugtakið er pekkt hjá fólki með proskahömlun sem manneskjan sem hefur völdin, „sá eða sú sem ræður yfir lífi fatlaðs fólks“ (Auður Finnbogadóttir, 2012). Hér má líka tengja við forræðishyggju og staðalmyndina að fólk með proskahömlun sé eilíf börn, geti ekki axlað ábyrgð og sé pví upp á annað fólk komið. GÆSarhópurinn óskaði í framhaldi af pessum viðræðum eftir pví að Reykjavíkurborg veitti styrk sem pau sjálf myndu ráđstafa og ráđa aðstoðarfólk sem hefði pað hlutverk að styðja pau sem stjórnendur eigin fyrirtækis eins og um sumarið. Dað var ekki sampykkt. GÆSarhópurinn hugðist leita styrkja og halda áfram prátt fyrir pað en eftir að hafa verið sagt upp húsnæðinu í Tjarnarbíói var kaffihúsinu lokað í september 2013. Ekki er hægt að túlka viðbrögð starfsfólks Reykjavíkurborgar á annan hátt en sem vanmat á getu fimmmenninganna og skilningsleysi á mannréttindasýn GÆSar sem byggir á samningi Sameinuðu pjóðanna um réttindi fatlaðs fólks (2013). GÆSarhópurinn mat pað svo að ef ráðin yrði „forstöðukona“ yfir verkefninu væri GÆS orðin verndaður vinnustaður en ekki pað frelsandi opna rými sem pau sjálf stjórnuðu. Viðbrögð Reykjavíkurborgar má í pessu samhengi tengja við ableisma með pví að ætla að pað sé hópnum fyrir bestu að ráða fyrir hann „,forstöðukonu“ og kollvarpa pannig rými GÆSar úr pví frelsandi rými sem hópurinn hafði skapað sér í rými ráðandi afla. Út frá kenningum um samtvinnun (Lykke, 2010) má álykta að pessar efasemdir sem fram komu um hæfni GÆSarmeðlima til að stjórna sínu eigin fyrirtæki kunni meðal annars að vera sprottnar af peirri hugmynd að pað séu forréttindi ákveðinna hópa ófatlaðs fólks að reka fyrirtæki og stjórna pví. Auk pess má leiða að pví líkur að auk fötlunar hafi stéttarstaða peirra, aldur og kyn samtvinnast í viðhorfum til hópsins. Fimmmenningarnir voru samkvæmir sjálfum sér og hugmyndafræði GÆSar, pau sampykktu ekki tillögur Reykjavíkurborgar, pau létu í sér heyra, bæði á Facebook-síðu sinni og í viðtölum. Dau skrifuðu einnig opið bréf til borgarráðs sem birtist í Fréttablaðinu par sem pau óskuðu eftir svörum (Menningarfélagið GÆS, 2013). Viðbrögð peirra sýna að pau höfnuðu peim staðalmyndum sem ætlast var til að pau sættu sig við, p.e. að pau væru pakklát og sampykktu pað sem að peim væri rétt. GÆSarhópurinn tók sér 
pannig rými og beitti andófi gegn ríkjandi viðhorfum til fólks með proskahömlun. Dað andóf sem GÆSarliðar sýndu er í anda hugmynda Foucault (1966-1976/2005) um að par sem vald er sé líka andóf (e. resistance). Pannig tóku pau sér ákveðna valdastöđu og mótmæltu pví viðhorfi að peim væri ekki treystandi svo og pví valdi sem starfsfólk Reykjavíkurborgar sýndi peim. Miklar pversagnir komu síðar fram í svörum starfsmanna Reykjavíkurborgar í fjölmiðlum, meðal annars pær að Reykjavíkurborg gæeti ekki staðið fyrir rekstri kaffihúss vegna samkeppnissjónarmiða (Flækir málið að borgin styrkir kaffi GÆS, 2013). GÆSarhópurinn var ekki að biðja um að Reykjavíkurborg ræki kaffihúsið heldur óskuðu pau eftir styrk til að halda verkefninu áfram. Reykjavíkurborg styrkir fjölbreytt verkefni og er með ýmsa pjónustu á sínum vegum sem er samkeppnishæf svo að pessi rök standast ekki. Petta hafði mikil áhrif á hópinn og pau misstu trú á verkefninu um tíma. Haustið 2013 var pví verulega erfiður tími fyrir frumkvöðlana fimm sem einn peirra lýsir hér:

Detta var svo langerfiðast hvernig komið var fram við okkur af peim parna í lokin.Við vildum ekki láta stjórna okkur. Рað erum við sem eigum að ráða. Раð á að vera pannig og ég bara fatta ekki af hverju petta parf að vera svona.

María P. Hreiðarsdóttir, ein af GÆSarliðum, hefur skrifað um reynslu sína af starfi sínu á GÆS í bók sinni „Ég lifði í pögninni“ - Lífssaga Maríu P. Hreiðarsdóttur (María P. Hreiðarsdóttir og Guðrún V. Stefánsdóttir, 2017). Par kemur fram að GÆS var í hennar huga stórkostlegt verkefni. Hún lýsti pví einnig hve sorgmædd hún var yfir endalokunum og ekki síst yfir peirri vantrú sem Reykjavíkurborg sýndi GÆSarhópnum. Hún benti líka á að á sama tíma og GÆS var að óska eftir styrk frá borginni var ráđin ófötluð manneskja til að sjá um atvinnumál fatlaðs fólks í borginni og pótti henni pað kaldhæðnislegt. María veltir fyrir sér ástæðunni fyrir viðbrögðum Reykjavíkurborgar og segir:

Kannski var pað vegna pess að við vildum sjálf ráða og reka kaffihúsið án afskipta borgarinnar. Ef til vill treystu yfirmenn borgarinnar okkur ekki til pess. Dannig er pað oft með viðhorf til fólks með proskahömlun. Fólk heldur að við getum ekki hitt og petta og að við eigum að láta ófatlaða fólkið um að stjórna (María P. Hreiðarsdóttir og Guðrún V. Stefánsdóttir, 2017, bls. 40-41).

Dessi framkoma endurspeglar ríkjandi viðhorf til fólks með proskahömlun, viðhorf sem byggjast á vanmati og forræðishyggju (Guðrún V. Stefánsdóttir o.fl., 2014). Detta er í algjörri andstöðu við bæði hugmyndir fimmmenninganna sem efuðust ekki um eigin getu til að sjá um og reka eigið fyrirtæki svo og peirra radda sem heyrðust í fréttaflutningi og á samfélagsmiðlum. Par var GÆS hyllt, hvatningarorðum rigndi yfir hópinn sem stóð að framtakinu og margir vildu aðstoða GÆS við að finna sér nýja framtíð.

\section{Samantekt og lokaorð}

Í greininni hefur verið leitast við að svara hvað einkenndi orðræðuna um kaffihúsið GÆS, hverjar séu helstu pversagnir hennar og hvernig orðræðan um GÆS mótaði reynslu stofnfélaganna fimm. Ætla má að orðræðan endurspegli á einhvern hátt almenna orðræðu um fólk með proskahömlun í samfélaginu, sérstaklega pegar kemur að sögulegum viðhorfum sem endurspegla vanmat á fólk með proskahömlun. Par er fatlað fólk sett í hlutverk krakka, gleðigjafa, ofurhetja og snillinga, jafnvel fyrir hversdagslegar athafnir. Dannig getur orðræðan verið meiðandi, gert lítið úr fólkinu og skyggt á pað hlutverk sem meðlimir GÆSar sinntu í raun, sem rekstraraðilar og kaffihúsaeigendur. Í mótsögn við pessa orðræðu komu líka fram merki um að GÆSarhópurinn hefði haft áhrif á viðhorf almennings með pví að ögra áður nefndum staðalmyndum og snúið á hvolf viðteknum hugmyndum um fólk með proskahömlun. 
Samkvæmt félagslegum skilningi á fötlun er áhersla lögð á að ögra hefðbundnum hugmyndum, viðhorfum og ímyndum um fatlað fólk og hafa pannig áhrif á menningu og samfélag í heild (Hanna Björg Sigurjónsdóttir o.fl., 2013; Shakespeare, 1998). Degar niðurstöður er skoðaðar í ljósi félagslegs skilnings á fötlun má álykta að GÆSarhópnum hafi tekist með styrk sínum að ryðja ákveðnum hindrunum úr vegi og beina sjónum að dugnaði og hæfileikum peirra sem í hlut áttu. Dau fengu greiðari aðgang að opinberri umræðu, til dæmis með fréttaflutningi, og almenningur fylgdist vel með peim og hafði áhuga á verkefninu. Jákvæðni orðræðunnar um GÆS hafði áhrif víða, ekki síst á stofnfélagana fimm sem fundu fyrir að hafa haft áhrif á viðhorf og pankagang fólks.

Niðurstöður rannsóknarinnar gefa líka til kynna að rýmið GÆS hafi verið frelsandi fyrir stofnfélagana fimm par sem pað var peirra sköpunarverk og par höfðu pau valdið í sínum höndum. Líta má á kaffihúsið og pað frelsandi rými sem varð til á GÆS sem nokkurs konar heterótópíu í anda Foucault (1966-1976/2005). Drátt fyrir velgengni og vinsældir GÆSar pá má hér merkja ableisma og í gegnum orðræðuna má greina hversu mikil áhrif hans eru, par sem pað er ekki reiknað með pví að fólk með proskahömlun geti rekið kaffihús. Pegar pað svo fær til pess tækifæri pá fær pað ekki langan tíma til að sanna sig, reynt er að svipta pað valdinu og breyta hugsjónum hópsins og hugsmíd. Dar má sérstaklega nefna ableiska framkomu peirra sem að verkefninu komu á vegum Reykjavíkurborgar og birtist meðal annars í skilningsleysi og vantrú á getu hópsins. Starfsfólk borgarinnar taldi sig vita betur hvað væri hópnum fyrir bestu og endurspeglar pað pá forræðishyggju sem hefur einkennt viðhorf til fólks með proskahömlun (Guðrún V. Stefánsdóttir, 2008; Kristín Björnsdóttir, 2009). Dví má álykta að kerfi borgarinnar hafi brugðist GÆSarhópnum með pví að sjá sér ekki fært að styðja pá mannréttindasýn sem einkenndi GÆS og réð að lokum úrslitum um að loka purfti kaffihúsinu. Đað er pví margt sem bendir til pess að enn sé pess langt að bíða að verkefni eins og GÆS geti blómstrað og átt sér trygga framtíð. Ísland er í pví ferli að lögleiða samning Sameinuðu pjóðanna um réttindi fatlaðs fólks (2013). Í samningnum kemur fram skýr mannréttindasýn sem til lengri tíma litið getur átt pátt 1 a d breyta viðhorfum og pankagangi fólks og pví kerfi sem er við lýði á Íslandi.

Niðurstöður benda líka til pess að orðræðan um GÆS hafi einkennst af ákveðnum pversögnum. Í peim fólst meðal annars að hópnum sem stóð að GÆS var annars vegar lýst sem hetjum en hins vegar sem krökkum og gleðigjöfum. Önnur pversögn pessa máls var sú að almenningur stóð með peim en Reykjavíkurborg brást peim. Annað hvort var fólkinu treyst fyrir GÆS eða alls ekki. Samkvæmt niðurstöðum pessarar rannsóknar má álykta að almenningur hafi átt sinn hlut i GÆS, hann hafi almennt haft trú á verkefninu og fólkinu sem að pví stóð, en að kerfið hafi hamlað framgöngu pess.

Að lokum er mikilvægt að draga fram pann styrk sem frumkvöðlarnir fimm sýndu með pví að vera tilbúin að deila lífssýn sinni, veita samfélaginu hlutdeild í GÆS og opna rýmið fyrir öllum sem pangað vildu koma. GÆSin mín og GÆSin pín tengdi saman ólíka hópa samfélagsins og á hana má líta sem eins konar sameiningartákn. Dessi grein er skrifuð fyrir stofnfélaga GÆSar en líka fyrir alla pví að samfélagið er miklu ríkara pegar allir fá tækifæri til að láta ljós sitt skína og sjá drauma sína ræatast.

\section{The discourse about Café GÆS}

Employment opportunities in the open labour market for people with intellectual disabilities have long been of a limited nature and often the only jobs on offer have been low-paid, with little opportunity for pay rise or promotion. It was, therefore, a watershed in labour market participation by people with intellectual disabilities when Café GÆS was opened in the premises of Tjarnarbíó in June 2013. For the first time in Iceland, people with intellectual disabilities established a company and took charge of all management as well as the front-of-the-house positions. Five graduates 
from a vocational diploma program for people with intellectual disabilities at the University of Iceland launched Café GÆS. One of the students came up with the idea to open a café run by disabled people. She wanted to see some drastic changes in job opportunities for disabled people and create a more accepting community in the labor market. The name GÆS means "goose" in Icelandic but is also acronym for "get, ætla, skal" (I can, I will, and I shall). The ideology of the project is derived from the United Nations Convention on the Rights of Persons with Disabilities. According to the convention, disabled people have the right to participate in society on an equal basis with others and are entitled to live in a community without discrimination. They also have equal rights to be employed and earn a living and to work in a disability friendly environment, as well as starting their own business with relevant support and backing.

This research reports on findings from an ethnographic study carried out in 2012 2014. The research falls within the field of disability studies whose academic approach critiques medical definitions of disability, emphasising, instead, the interplay of impairments and environment and the importance of human rights for disabled people. The aim of the research was to identify and analyse the discourse on Cafe GÆSS, which received significant coverage in news and online media. A particular emphasis was placed on the way people's perspectives of intellectual disability were reflected in the discourse. In addition, a special effort was made to explore how the discourse shaped the five founding individuals' life experiences; for this purpose, participant observations were carried out in the café and both individual and focus group interviews were conducted with them. The data was analysed by means of discourse analysis and thematic analysis. The results of the research suggest that the discourse on GÆS in some ways reflects the general social discourse on people with intellectual disabilities, particularly with respect to historical views which mirror a devaluation, placing them in the roles of kids, sources of joy and amusement, superheroes and geniuses, even with reference to everyday activities. In contradiction to those perspectives there were also indications that the GÆS group has altered people's views by challenging the above-mentioned stereotypes and reversing accepted notions relating to people with intellectual disabilities. Thus, one might conclude that GÆS has contributed to a more open discourse on the skills and competences of people with intellectual disabilities. The findings also indicate that the discourse on GÆS was characterised by positive attitudes towards the group which established the café. This, among other things, was manifested in considerable media interest and goodwill towards the café. But in contrast to the conclusions outlined above, the discourse was also coloured by ableism and stereotypes of people with disabilities, attitudes which are, for example, demonstrated by regarding them as eternal children who cannot assume responsibilities. Ableism presumes that disability is a certain divergence from the norm and that people who are not disabled should always be socially classified over and above those with disabilities. There is some likelihood, therefore, that notions of ableism have led to the expression of doubts regarding their ability to run a café and that this later became a weighty reason for the operation being wound up.

Key words: People with intellectual disabilities, employment participation, human rights, discourse, disability studies. 


\title{
Um höfundana
}

Ágústa Rós Björnsdóttir (agusbjo@hi.is) starfar sem verkefnastjóri starfstengds diplómanáms fyrir fólk með proskahömlun á Menntavísindasviði Háskóla Íslands. Hún lauk meistaraprófi í uppeldis- og menntunarfræði við Háskóla Íslands árið 2018. Ágústa hefur tekið pátt í rannsóknum sem tengjast lífi, reynslu og pátttöku fólks með proskahömlun.

Dr. Jón Ingvar Kjaran (jik@hi.is) er sérfræðingur við Jafnréttisskóla Háskóla Sameinuðu pjóðanna. Hann er jafnframt dósent við Deild menntunar og margbreytileika á Menntavísindasviði Háskóla Íslands. Áherslur hans í rannsóknum eru kynjajafnrétti, kynhneigð, félagsfræði menntunar, kynbundið ofbeldi og fjölmenning.

\begin{abstract}
About the authors
Ágústa Rós Björnsdóttir (agusbjo@hi.is) works as a project manager at the University of Iceland, School of Education, and supervises vocational diploma programs for students with intellectual disabilities. She completed an MA degree in educational studies from the University of Iceland, School of Education, in 2018. Her participation in research has been in the field of disability studies, focusing on experiences and perceptions of people with intellectual disabilities.

Dr. Jón Ingvar Kjaran (jik@hi.is) is senior researcher at UNU-GEST, United Nations University Gender Equality Studies and Training Programme. He is also associate professor at the University of Iceland, School of Education / Faculty of Diversity and Education. His research focus is on gender equality, sexuality, ethnicity, sociology of education, and gender violence. See further: https://uni. hi.is/jik/
\end{abstract}

\section{Heimildir}

Aol. (2013). Tim's Place Albuquerque's service with a smile | You've got [myndband]. Sótt af https://www.youtube.com/ watch? $\mathrm{v}=\mathrm{y} 6 \mathrm{He} 0 \mathrm{FWoFj} 0$

Atkinson, P. og Hammersley, M. (2007). Ethnography: Principles in practice. London: Routledge.

Auður Finnbogadóttir. (2012). Skjólstæðingur minn eða vinnuveitandi - skiptir pað máli? Uppeldi og menntun, 21(1), 121-127.

Bogdan, R. og Biklen, S. (1998). Qualitative research for education: An introduction to theory and methods (3. útgáfa). Boston: Allyn \& Bacon.

Bogdan, R. og Biklen, S. (2003). Qualitative research in education: An introduction to theories and methods (4. útgáfa). Boston: Allyn \& Bacon.

Braun,V. og Clarke,V. (2013). Successful qualitative research: A practical guide for beginners. London: Sage.

Campell, F. K. (2009). Contours of ableism: The production of disability and abledness. Basingstoke: Palgrave Macmillan.

Carlson, L. (2001). Cognitive ableism and disability studies: Feminist reflections on the history of mental retardation. Hypatia, 16(4), 124-146.

Creswell, J. W. (2007). Qualitative inquiry and research design: Choosing among five approaches (2. útgáfa). Thousand Oaks, CA: Sage.

de Certeau, M. (1984). The practice of everyday life. Berkeley, CA: University of California Press.

Esterberg, K. G. (2002). Qualitative methods in social research. Boston: McGraw Hill. 
Eva Dórdís Ebenezersdóttir. (2014). Haltrað í tveimur heimum: Skilningur á fötlun og skerðingum í íslenskum pjóðsögum fyrir 1900 (meistararitgerð). Sótt af http://skemman.is/handle/1946/17315

Félagsvísindastofnun Háskóla Íslands. (2011). Flutningur pjónustu við fatlað fólk frá ríki til sveitarfélaga: Október 2011 - Kortlagning á stöðu pjónustunnar fyrir flutning [úttekt unnin fyrir velferðarráðuneytið]. Reykjavík: Höfundur.

Flækir málið að borgin styrkir kaffi GÆS. (2013, 20. september). Ruv.is Sótt af http://www.ruv.is/frett/flaekir-malidad-borgin-styrkir-kaffi-gaes

Foucault, M. (1972). The archaeology of knowledge and the discourse of language. New York: Tavistock.

Foucault, M. (1998). The will to knowledge: The history of sexuality. Vol. 1 (R. Hurley pýddi). London: Penguin Books.

Foucault, M. (2002). Um önnur rými (Benedikt Hjartarson pýddi). Ritið: Tímarit Hugvísindastofnunar Háskóla Íslands, $2(1), 131-142$.

Foucault, M. (1966-176/2005). Alsai, vald og pekking (Björn Dorsteinsson, Garðar Baldvinsson og Sigurður Ingólfsson pýddu). Reykjavík: Bókmenntafræðistofnun Háskóla Íslands.

Fólk beðið um að leggja til bolla. (2013, 8. maí). visir.is. Sótt af http://www.visir.is/g/2013705089943/folk-bedid-umad-leggja-til-bolla

Garðar Örn Úlfarsson. (2013, 11. apríl). Proskahamlaðir opna kaffihús í Tjarnarbíói. Fréttablaðið. Sótt af http://www. visir.is/paper/fbl/130411.pdf

Goodley, D. (2011). Disability studies: An interdisciplinary introduction. Thousand Oaks, CA: Sage.

Goodley, D. (2014). Disability studies: Theorising disableism and ableism. New York: Routledge.

Guðrún V. Stefánsdóttir. (2008). „Ég hef svo mikið að segja”: Lifssögur Íslendinga með proskahömlun á 20. öld (doktorsritgerð). Háskóli Íslands, Félagsvísindadeild.

GuðrúnV. Stefánsdóttir. (2013). Atvinnupátttaka fólks með proskahömlun sem lokið hefur starfstengdu diplómanámi frá Háskóla Íslands. Tímarit um menntarannsóknir, 10(1), 85-103.

Guðrún V. Stefánsdóttir, Kristín Björnsdóttir og Ástríður Stefánsdóttir. (2014). „Má ég fá að ráđa eigin lífi?“ Sjálfræði og fólk með proskahömlun. Uppeldi og menntun 23(2), 21-41.

Hagner, D. (2000). Coffee breaks and birthday cakes: Evaluating workplace cultures to develop natural supports for employees with disabilities. St. Augustine, FL:Training Resource Network.

Hanna Björg Sigurjónsdóttir. (2008). Orðræða um seinfæra foreldra í netheimum. Í Gunnar Pór Jóhannesson og Helga Björnsdóttir (ritstjórar), Rannsóknir í félagsvísindum IX (bls. 413-421). Reykjavík: Félagsvísindastofnun Háskóla Íslands.

Hanna Björg Sigurjónsdóttir, Ármann Jakobsson og Kristín Björnsdóttir. (2013). Inngangur: Rannsóknir á fötlun og menningu. Í Hanna Björg Sigurjónsdóttir, Ármann Jakobsson og Kristín Björnsdóttir (ritstjórar), Fötlun og menning: Íslandssaga íöðru ljósi (bls. 7-25). Reykjavík: Félagsvísindastofnun Háskóla Íslands og Rannsóknarsetur í fötlunarfræðum.

Ingólfur Ásgeir Jóhannesson. (2006). Leitað að mótsögnum: Um verklag við orðræðugreiningu. Í Rannveig Traustadóttir (ritstjóri), Fötlun: Hugmyndir og aðferđir á nýju freðasviði (bls. 178-195). Reykjavík: Háskólaútgáfan.

Johnson, K. (2005). Moving out: Reflection. Í K. Johnson og R. Traustadóttir (ritstjórar), Institutionalization and people with intellectual disabilities: In and out of institutions (bls. 145-156). London: Jessica Kingsley.

John's crazy socks. (2017). Sótt af https://johnscrazysocks.com

Jón Ingvar Kjaran og Ingólfur Ásgeir Jóhannesson. (2015). Inclusion, exclusion and the queering of spaces in two Icelandic upper secondary schools. Ethnography and Education, 10(1), 42-59. doi:10.1080/17457823.2014.925409

Kaffihús fatlaðra fær verðlaun. (2013). Dv.is. Sótt af http://www.dv.is/frettir/2013/12/3/kaffihus-fatladra-faer-verdlaun/

Kristín Björnsdóttir. (2006). Öll í sama liði. Í Úlfar Hauksson (ritstjóri), Rannsóknir í félagsvísindum VII: Félagsvísindadeild (bls. 303-314). Reykjavík: Félagsvísindastofnun Háskóla Íslands.

Kristín Björnsdóttir. (2009). Resisting the reflection: Social participation of young adults with intellectual disabilities (doktorsritgerð). Háskóli Íslands, Félagsvísindadeild.

Kristín Björnsdóttir og Ingólfur Ásgeir Jóhannesson. (2013). Margrödduð orðræða í tímaritum samtaka fatlaðs fólks. Í Hanna Björg Sigurjónsdóttir, Ármann Jakobsson og Kristín Björnsdóttir (ritstjórar), Fötlun og menning: Íslandssaga í öðru ljósi (bls. 257-277). Reykjavík: Félagsvísindastofnun Háskóla Íslands.

Kristín Björnsdóttir og Kristín Stella L’orange. (2014). „Engar hendur, ekkert súkkulaði“: Kyngervi, hörundslitur, fötlun og stétt 1 kvikmyndinni Intouchables. Netla - veftímarit um uppeldi og menntun. Sótt af http://netla.hi.is/greinar/2014/ ryn/009.pdf

Lefebvre, H. (1991). The production of space. Oxford: Blackwell.

Lykke, N. (2010). Feminist studies: A guide to intersectional theory, methodology and writing. New York: Routledge.

Margrét Magnúsdóttir. (2010). Atvinnumál fatlaðs fólks: Pátttaka á almennum vinnumarkaði með stuðningi (meistararitgerð). Háskóli Íslands, Félagsvísindadeild. 
María P. Hreiðarsdóttir og GuðrúnV. Stefánsdóttir. (2017). „Ég lifði i pögninni “: Lifssaga Maríu D. Hreiðarsdóttur. Reykjavík: Bókaútgáfan Draumórar.

Menningarfélagið GÆS. (2013, 24. október). Opið bréf til borgarráðs. visir.is. Sótt af http://www.visir.is/g/2013710249983

Oliver, M. (1990). The politics of disablement. Basingstoke: MacMillan.

Rannveig Traustadóttir. (2006). Í nýjum fræðaheimi: Upphaf fötlunarfræða og átök ólíkra hugmynda. Í Rannveig Traustadóttir (ritstjóri), Fötlun: Hugmyndir og aðferđir á nýju freeđasviði (bls. 13-36). Reykjavík: Háskólaútgáfan.

Samningur Sameinuðu pjóðanna um réttindi fatlaðs fólks. (2013). Sótt af https://www.stjornarradid.is/efst-a-baugi/ frettir/stok-frett/2009/06/10/Samningur-Sameinudu-thjodanna-um-rettindi-fatlads-folks/

Shakespeare, T. (1998). The disability reader: Social science perspectives. London: Cassell.

Shakespeare, T. (2006). Disability rights and wrongs. London: Routledge.

Shildrick, M. (2017). Critical disability studies: Rethinking the conventions for the age of postmodernity. Í N. Watson, A. Roulsone og C. Thomas (ritstjórar), Routledge handbook of disability studies (bls. 30-41). London: Routledge.

Silverman, D. (2010). Doing qualitative research: A practical handbook (3. útgáfa). London: Sage.

Tøssebro, J. (2004). Introduction to the special issue: Understanding disability. Scandinavian Journal of Disability Research, $6(1), 3-7$.

Velferðarráðuneytið. (2013). Djónusta sveitarfélaga við fatlað fólk:Tölulegar upplýsingar vegna ársins 2011. Sótt af http://www. velferdarraduneyti.is/rit-og-skyrslur-vel/nr/34292

Wistow, R. og Schneider, J. (2003). Users' views on supported employment and social inclusion: A qualitative study of 30 people in work. British Journal of Learning Disabilities, 31(4), 166-174.

Ágústa Björnsdóttir og Jón Ingvar Kjaran. (2019).

„GÆSin mín og GÆSin pín, Egils malt og appelsín“

Netla - Veftímarit um uppeldi og menntun. Menntavísindasvið Háskóla Íslands.

Sótt af http://netla.hi.is/greinar/2019/ryn/06

DOI: https://doi.org/10.24270/netla.2019.6 